\title{
Restrukturisasi Organisasi Perangkat Daerah Kecamatan di Kabupaten Kolaka Utara
}

\author{
Taufik Hidayat \\ Program Pascasarjana Magister Administrasi Publik \\ Universitas Muhammadiyah Makassar \\ Makassar,Indonesia \\ Email:taufik.hidayat@gmail.com
}

\begin{abstract}
This study aims to analyze the process of organizational restructuring of regional devices in the scope of North Kolaka District Government (Case Study of Tiwu and Lasusua Sub-districts) and analysis of typology and size of the organization of the Kecamatan. This research was conducted in North Kolaka Regency using mix method approach. The research shows that the process of restructuring of regional apparatus organization in North Kolaka district especially in Tiwu District and Lasusua sub-district institutional redesign has not been through the stages and process of effective and efficient institutional arrangement, the formation process of the formulation team, the political process of policy determination, the process of determining type and magnitude of sub-district organization, organizational structure and working procedures, duties and sub-district functions that overlap one affair with other affairs, and the lack of socialization of institutional arrangement policy so that the process of organizational restructuring of sub-district has not been rational, effective and efficient as well as determination of tipelogi and the size of Tiwu and Lasusua sub-district organizations have not been based on analysis of the main workload of government affairs in general variables and technical variables in a rational, effective and efficient manner.
\end{abstract}

Keywords: Restructuring; Organizations; Devices Regions

\begin{abstract}
Abstrak
Penelitian ini bertujuan menganalisis proses restrukturisasi organisasi perangkat daerah di lingkup Pemerintah Kabupaten Kolaka Utara (Studi Kasus Kecamatan Tiwu dan Kecamatan Lasusua) dan analisis tipelogi dan besaran organisasi Kecamatan tersebut. Penelitian ini dilaksanakan di Kabupaten Kolaka Utara dengan menggunakan pendekatan mix method. Penelitian menunjukkan proses restrukturisasi organisasi perangkat daerah di Kabupaten Kolaka Utara khususnya dalam redesain kelembagaan Kecamatan Tiwu dan Kecamatan Lasusua, belum melalui tahapan-tahapan dan proses penataan kelembagaan yang efektif dan efisien, proses pembentukan tim perumus (kepanitiaan), proses politik penetapan kebijakan, proses penentuan tipe dan besaran organisasi Kecamatan, Struktur Organisasi dan Tata Kerja, Tugas Pokok dan Fungsi Kecamatan yang tumpang tindih antara satu urusan dengan urusan yang lain, serta kurangnya sosialisasi kebijakan penataan kelembagaan sehingga belum terwujudnya proses restrukturisasi organisasi Kecamatan yang rasional, efektif dan efisien serta penentuan tipelogi dan besaran organisasi Kecamatan Tiwu dan Kecamatan Lasusua belum berdasarkan analisis beban kerja utama urusan pemerintahan dalam variabel umum dan variabel teknis secara rasional, efektif dan efisien.
\end{abstract}

Kata Kunci: Restruturisasi; Organisasi;Perangkat Daerah

Link DOI : http://dx.doi.org/10.31314/pjia.7.1.29-43.2018

Copyright @ 2018, Publik : (Jurnal Ilmu Administrasi), ISSN: 2301-573X (Print), ISSN: 2581-2084 (Online) 


\section{PENDAHULUAN}

Perjalanan sistem desentralisasi di Indonesia jika dirunut sepanjang sejarah perjalanan bangsa ini cukup panjang dan berliku. Perubahan politik di tahun 1990an menjadi arus balik perjalanan bangsa Indonesia yang membawa beberapa dampak positif. Perubahan tersebut di antaranya mengubah tata hubungan antara Pemerintah Pusat dan Daerah ke arah yang lebih demokratis dengan memperbesar porsi desentralisasi. Dengan perubahan sistem pemerintahan tersebut, otomatis berbagai pranata pendukung sistem yang selama ini bersifat sentralistik juga mengalami perubahan (Usman, 2011). Selain itu konsekuensi dari terbitnya Peraturan Pemerintah Nomor 18 Tahun 2016 tentang perangkat daerah mewajibkan bagi seluruh daerah otonom yang ada untuk melakukan penataan, restrukturisasi kelembagaan organisasi, dan menyesuaikan dengan regulasi yang baru.

Selain itu Manajemen profesional pelayanan publik harus lebih berorientasi pada tujuan paradigma pemerintahan yang didasarkan pada pendekatan manajemen baru, baik secara teori maupun praktis (Usman, 2011). Oleh karena itu, Pemerintah Kabupaten Kolaka Utara adalah salah satu daerah otonom yang wajib untuk mengimplementasikan pedoman dan peraturan baru tersebut dalam rangka tidak hanya melaksanakan kewajiban pembentukan peraturan daerah akan tetapi untuk membentuk organisasi perangkat daerah yang efektif, efisien dan rasional, serta memenuhi prinsip-prinsip good governance, miskin struktur dan kaya akan fungsi, lahirnya kelembagaan pemerintah daerah yang ramping, serta pada akhirnya menerapkan prinsip the right man on the right place, akan tetapi tujuan tersebut tidak sejalan dengan kondisi perilaku aparatur birokrasi dalam mengemban amanah sebagai abdi negara.

Terbentuknya organisasi perangkat daerah yang besar mengakibatkan terjadinya tumpang tindih implementasi tugas pokok dan fungsi antar organisasi yang ada. Ada berbagai keragaman organisasi perangkat daerah yang dibentuk oleh pemerintah daerah menciptakan potensi terjadinya duplikasi pelaksanaan tugas pokok dan fungsi. Kondisi tersebut selain menciptakan sulitnya koordinasi dan konsultasi pada tataran implementasi kebijakan publik juga berakibat pada pemborosan penggunaan sumber daya yang ada di daerah, baik sumber daya manusia dan sumber daya finansial (anggaran) daerah. Banyaknya keragaman organisasi yang dibangun juga menciptakan semakin banyak kemungkinan terciptanya garis konflik di antara organisasi perangkat daerah itu sendiri. Konflik antar organisasi perangkat daerah diakibatkan oleh adanya rebutan tugas, sinyalemen ini selain akan menyebabkan inefisiensi dan inefektifitas terhadap organisasi juga berakibat terbengkalainya pelayanan publik. Apalagi Pelayanan kepada masyarakat sudah menjadi tujuan utama dalam penyelenggaraan administrasi publik. Di Indonesia penyelenggaraan pelayanan publik menjadi isu kebijakan yang semakin strategis karena perbaikan pelayanan publik di negara ini cenderung berjalan di tempat, sedangkan implikasinya sebagaimana diketahui sangat luas karena menyentuh seluruh ruang-ruang kepublikan baik dalam kehidupan ekonomi, sosial, politik,budaya dan lainlain (Mahsyar, 2011).

Masalah birokrasi yang dihadapi oleh pemerintah Kabupaten Kolaka Utara sehubungan dengan restrukturisasi yang didasarkan pada Peraturan Pemerintah 
Nomor 18 Tahun 2016. Pertama, dalam aspek kelembagaan terjadi penyempitan struktur kelembagaan. Hal ini akan menimbulkan beberapa jabatan hilang dan dirasakan oleh ASN di lingkungan Pemerintah Kolaka Utara. Akan tetapi di sisi lain, akan terjadi efisiensi anggaran (sesuai dengan tujuan PP 18 Tahun 2016). Kedua, belum melembaganya karakteristik good governance di dalam pemerintahan daerah, baik dari segi struktur dan kultur serta nomenklatur program yang mendukungnya. Sampai sekarang penerapan kaidah good governance di pemerintah daerah masih bersifat sloganistik. Dalam konteks Indonesia yang bergeliat dengan tuntutan reformasi, good governance tampil sebagai model transplantatif baru yang diyakini mampu mengobati birokrasi politik yang dinilai sarat korupsi, suap, dan penyalahgunaan kekuasan, termasuk berbagai pelanggaran hak-hak asasi manusia (Prianto, 2011).

Ketiga, yang muncul di bidang kelembagaan yaitu dilema terhadap penciutan (likuidasi) lembaga-lembaga daerah. Sebagaimana diketahui pelaksanaan otonomi daerah dipengaruhi oleh empat faktor, yaitu pendanaan, personil, peralatan, dan pengelolaan. Apabila keempat faktor itu dikembangkan di daerah, maka biasanya akan menimbulkan kendala pendanaan. Untuk itu jalan pintas yang dapat dilakukan adalah dengan melikuidasi lembagalembaga daerah. Keempat, keberlanjutan pembangunan daerah memerlukan institusi lokal yang mampu dan berdaya dalam menghadapi tantangan dan perubahannya. Saat ini memang ada upaya-upaya untuk membentuk institusi baru, tetapi tidak memperhatikan keberadaan-keberadaan institusi yang mungkin jika ditingkatkan dan diberdayakan, dapat menjalankan peran baru dan menjawab berbagai tantangan baru. Institusi-insitusi itu harus Copyright @ 2018, Publik : (Jurnal Ilmu Administrasi), ISSN: 2301-573X (Print), ISSN: 2581-2084 (Online) mampu mewadahi perubahan di segala aspek sosial, politik, ekonomi dan budaya. Kelima, restrukturisasi kelembagaan akan mengakibatkan penganguran terselubung atau dipensiunkan. Akibatnya, banyak daerah akan menerima beban permasalahan sosial dan ekonomi yang bertambah berat. Keenam, permasalahan profesionalisme tidak berjalan, sehingga berpengaruh kepada kelembagaan. Dinamika perkembangan masyarakat sangat cepat, dengan permasalahan yang semakin multidimensional, menuntut pemerintah Kabupaten Kolaka Utara menangani permasalahan daerah secara tepat dan profesional. Apalagi Besarnya pengaruh komunikasi secara informal terhadap penyusunan dokumen perencanaan yang mengakibatkan daya tarik Musrenbang kurang kuat untuk mewujudkan perencanaan partisipatif. Dengan kata lain, penentuan program dan kegiatan prioritas justru efektif dilakukan melalui komunikasi informal yang dilakukan secara "invisible hand" oleh masyarakat terhadap pemerintah maupun penentu kebijakan (Adaby, 2013).

Permasalahan lainnya adalah meningkatnya kecenderungan untuk merekrut dan mempromosikan pegawai yang merupakan putra asli daerah, sehingga sistem penerimaan pegawai ASN sering kali tidak diawali dengan analisis kebutuhan yang rasional, tetapi lebih pada pertimbangan emosional dan euforia reformasi yang masih banyak dirasakan di daerah-daerah. Di samping itu, ditemukan juga adanya beberapa pejabat daerah yang terlibat korupsi kolusi dan nepotisme, birokrasi lamban, tidak responsif, tidak transparan, dan sebagainya khususnya dalam lingkup pemerintah Kabupaten Kolaka Utara.

Selain itu, kecamatan yang ada di Kabupaten Kolaka Utara sangat heterogen dari segi luas wilayah, jumlah penduduk, 
dan jumlah desa / kelurahan antara satu kecamatan dengan kecamatan yang lain. Indikator tersebut merupakan variabel teknis dalam pembentukan organisasi kecamatan. Oleh karena itu, dari 15 jumlah kecamatan tersebut apabila merujuk pada Peraturan Pemerintah Nomor 18 Tahun 2016 terdapat perbedaan-perbedaan tipelogi antara satu kecamatan dengan kecamatan yang lain. Pembentukan kecamatan sebagai organisasi perangkat daerah tidak sesuai dengan Peraturan Pemerintah Nomor 18 Tahun 2016, yaitu melakukan penyeragaman organisasi kecamatan dengan tipe A sebagaimana dijelaskan dalam Peraturan Daerah Nomor 3 Tahun 2016. Sehingga, apabila mengamati perbedaan yang jauh antara Kecamatan Tiwu dan Kecamatan Lasusua dilihat dari indikator jumlah penduduk, luas wilayah dan jumlah Desa/Kelurahan maka kedua Kecamatan tersebut akan melahirkan dua tipelogi Kecamatan yang berbeda pula.

Oleh karena itu, peneliti tertarik untuk mengetahui lebih dalam terkait bagaimana proses restrukturisasi organisasi perangkat daerah khususnya terkait dengan lingkup desain kelembagaan organisasi kecamatan yang baru, sehingga penelitian ini diformulasikan dengan judul "Restrukturisasi Organisasi Perangkat Daerah Kecamatan di Kabupaten Kolaka Utara" (Studi Kasus: Kecamatan Tiwu dan Kecamatan Lasusua).

\section{METODE PENELITIAN}

Jenis penelitian yang gunakan oleh penulis adalah jenis penelitian dengan mix method. Lokasi penelitian akan dilaksanakan di Kabupaten Kolaka Utara Provinsi Sulawesi Tenggara sebagai daerah mengimplementasikan Peraturan Pemerintah Nomor 18 Tahun 2016 Tentang Perangkat Daerah serta kecenderungan terjadinya implementasi kebijakan penataan organisasi yang tidak efektif, efisien serta tidak berpedoman pada parameter yang ditentukan. Adapun Organisasi Perangkat Daerah (OPD) sebagai lokasi penelitian adalah Kantor Bupati Kolaka Utara melalui Bagian Organisasi dan Tata Laksana Sekretariat Daerah, Bagian Hukum Sekretariat Daerah, Badan Kepegawaian dan Pengembangan Sumber Daya Manusia, Badan Keuangan Daerah, Kecamatan Tiwu dan Kecamatan Lasusua. Sedangkan waktu penelitian dilaksanakan selama periode waktu dua bulan setelah seminar proposal penelitian .

Sumber data terdiri dari data primer dan data sekunder, teknik analisis data dan penentuan informan ditentukan secara heterogen yang terdiri atas unsur eksekutif (pegawai ASN, Setda, Kecamatan) dan unsur legislatif yang berjumlah 9 orang. Teknik pengumpulan data menggunakan teknik observasi, dokumentasi dan wawncara.

Teknik analisis data Miles dan Huberman dalam Sugiyono (2017) bahwa aktivitas dalam analisis data, yaitu : data reduction, data display, dan conclusion drawing / verification. Teknik pengabsahan data menggunakan teknik perpanjangan masa pengamatan, teknik meningkatkan ketekunan, dan triangulasi

\section{HASIL DAN PEMBAHASAN}

\section{Gambaran Administrasi Pemerintah Kabupaten Kolaka Utara}

Sejak Oktober 2006, berdasarkan Perda Kabupaten Kolaka Utara No. 03 Tahun 2006 wilayah administrasi pemerintahan Kabupaten Kolaka Utara mengalami pemekaran dari 6 kecamatan menjadi 12 kecamatan. Pada 5 Desember 2007, berdasarkan Perda Kabupaten Kolaka Utara No. 14 Tahun 2007 

merupakan pemekaran dari Kecamatan Lasusua. Pada tahun 2008, berdasarkan Perda Kabupaten Kolaka Utara No 17 Tahun 2008, terbentuklah Kecamatan Tiwu dan Tolala. Wilayah administrasi pemerintahan Kabupaten Kolaka Utara keadaan tahun 2014 terdiri atas 15 kecamatan, 127 desa, dan 6 kelurahan. Jumlah anggota DPRD berjumlah 25 orang. Selain itu, jumlah personel perlindungan masyarakat berjumlah 681 orang yang tersebar diseluruh wilayah.

Pegawai Negeri Sipil (PNS) lingkup pemerintah Kabupaten Kolaka Utara berjumlah 3.664 yang tersebar di seluruh instansi dan organisasi perangkat daerah.

Tabel 1. Keadaan PNS berdasarkan kualifikasi pendidikan di Kab. Kolaka Utara

\begin{tabular}{|c|c|c|}
\hline No & $\begin{array}{c}\text { Pendidikan } \\
\text { Terakhir }\end{array}$ & $\begin{array}{c}\text { Jumlah } \\
\text { PNS }\end{array}$ \\
\hline 1 & SD/Sederajat & - \\
\hline 2 & SMP/Sederajat & 11 \\
\hline 3 & SMA/Sederajat & 428 \\
\hline 4 & Diploma I, II & 238 \\
\hline \multirow[t]{2}{*}{5} & Diploma III & 481 \\
\hline & Sarjana Muda & \\
\hline \multirow[t]{2}{*}{6} & $\mathrm{~S} 1 / \mathrm{S} 2 / \mathrm{S} 3$ & 2.506 \\
\hline & Jumlah & 3.664 \\
\hline
\end{tabular}

Sumber : BKP SDM Kab. Kolut, 2017

\section{Restrukturisasi Organisasi Perangkat Daerah Kabupaten Kolaka Utara (Studi Kasus Kecamatan Tiwu dan Kecamatan Lasusua)}

Proses restrukturisasi organisasi perangkat daerah di Kabupaten Kolaka Utara khususnya terkait dengan pembentukan restrukturisasi organisasi Kecamatan dianalisis menggunakan indikator dalam Peraturan Pemerintah Nomor 18 tahun 2016 tentang Perangkat Daerah, yaitu penentuan struktur organisasi Kecamatan Tipe A terdiri dari 1 sekretariat, 2 sub bagian, dan 5 seksi. Sedangkan Kecamatan tipe B, terdiri dari 1 terbentuklah Kecamatan Katoi yang

sekretariat, 2 sub bagian dan 3 seksi. Adapun proses penyusunan organisasi kecamatan tersebut melalui beberapa proses sebagaimana hasil wawancara penulis dengan beberapa informan sebagai berikut:

"restrukturisasi atau penataan

kelembagaan dilakukan melalui tahapan-tahapan sebagaimana dijelaskan dalam Peraturan Pemerintah Nomor 18 Tahun 2016 (wawancara, " $R$ ", Kasubag Kelembagaan, Bagian Ortala Setda, 29 Oktober 2017)

Selain itu, hal senada juga disampaikan oleh Kepala Bagian Organisasi dan Tata Laksana, Sekretariat Daerah Kabupaten Kolaka Utara sebagai berikut :

"proses restrukturisasi organisasi khususnya di tingkat organisasi Kecamatan dilakukan dengan beberapa tahapan. Namun, OPD secara keseluruhan proses restrukturisasi dilakukan secara keseluruhan di setiap OPD karena tuntutan kebijakan pusat (wawancara "I”, Kepala Bagian Ortala Setda, 29 Oktober 2017)

Disisi lain, Sekretaris Daerah Kabupaten Kolaka Utara memberikan penjelasan secara detail tentang proses restrukturisasi organisasi dan penataan kelembagaan organisasi perangkat daerah di Kabupaten Kolaka Utara. Adapun penjelasannya sebagai berikut :

"proses restrukturisasi organisasi dilakukan dalam rangka untuk melakukan penataan dan penyesuaian terhadap regulasi yang baru, yang dikeluarkan oleh pemerintah pusat (wawancara "IR", Sekretaris Daerah, 30 Oktober 2017)

Senada dengan pernyataan tersebut, Asisten I Bidang Pemerintahan Sekretariat Daerah Kabupaten Kolaka Utara Copyright (C) 2018, Publik : (Jurnal Ilmu Administrasi), ISSN: 2301-573X (Print), ISSN: 2581-2084 (Online) 
memberikan penjelasan tambahan tentang pelaksanaan restrukturisasi organisasi dan penataan kelembagaan organisasi perangkat daerah di Kabupaten Kolaka Utara. Adapun butir penjelasannya sebagai berikut :

"penyesuaian terhadap regulasi yang baru merupakan tuntutan yang harus dipenuhi dan dilaksanakan tidak hanya OPD di Kabupaten Kolaka Utara. Akan tetapi, di seluruh jajaran pemerintah daerah baik Provinsi maupun Kabupaten/Kota yang mengimplementasikan PP 18 Tahun 2016 tersebut (wawancara " $Z B$ "

Asisten I Setda, 1 November 2017)

Demikian pernyataan dari beberapa informan tersebut, yang memberikan penjelasan terkait proses restrukturisasi organisasi perangkat daerah di Kabupaten Kolaka Utara khususnya dalam penataan dan restrukturisasi organisasi Kecamatan Tiwu dan Kecamatan Lasusua dalam kaitannya dalam proses awal penyusunan naskah akademik, naskah politik dan naskah hukum serta pembahasannya di lembaga legislatif.

Proses restrukturisasi organisasi perangkat daerah Kabupaten Kolaka Utara khususnya organisasi Kecamatan Tiwu dan Kecamatan Lasusua dilakukan berdasarkan Peraturan Pemerintah Nomor 18 Tahun 2016 tentang Perangkat Daerah. Setelah itu, ditindaklanjuti melalui kebijakan yang dikeluarkan oleh Pemerintahan daerah Kabupaten Kolaka Utara melalui Peraturan Daerah Nomor 3 Tahun 2016 tentang Pembentukan dan Susunan Perangkat Daerah Kabupaten Kolaka Utara Pasal 3 ayat (2) huruf c bahwa Kecamatan Tiwu dengan Tipe A, dan huruf a bahwa Kecamatan Lasusua dengan tipe A, hal tersebut berarti bahwa Kecamatan Tiwu dan Kecamatan Lasusua berdasarkan hasil analisis tersebut dibentuk dengan dengan beban kerja yang besar, yang berimplikasi pada struktur organisasi yang terdiri dari 1 Sekretariat, 2 Sub Bagian dan paling banyak 5 seksi.

Proses restrukturisasi tidak melalui proses dan tahapan penataan kelembagaan yang efektif dan efisien. Proses penataan kelembagaan organisasi Kecamatan Tiwu dan Kecamatan Lasusua secara umum masih mempunyai berbagai kelemahankelemahan seperti lambatnya pembentukan kepanitiaan / tim perumus/ analis kelembagaan organisasi Kecamatan, hasil analisis pemerintah daerah dalam pembentukan Struktur Organisasi dan Tata Kerja (SOTK), bagan alir dalam struktur organisasi dan jumlah lini dalam struktur organisasi belum memperhatikan aspek rasionalitas dalam desain kelembagaan.

Proses restrukturisasi organisasi perangkat daerah tersebut tidak dilakukan dengan analisis beban kerja utama yang rasional berdasarkan variabel umum dan variabel teknis sebagaimana ditetapkan dalam lampiran peraturan pemerintah. Proses restrukturisasi organisasi tidak melalui tahapan dan prosedur penyusunan dan formulasi kebijakan yang benar. Pembentukan organisasi perangkat daerah khususnya Kecamatan Tiwu dan Kecamatan Lasusua dilakukan dengan lambatnya pembentukan kepanitiaan, tim penyusun atau tim perumus dalam analisis beban kerja utama urusan pemerintahan yang terdapat dalam variabel umum dan variabel teknis. Oleh karena itu, kebijakan tersebut lahir tidak dengan analisis dan pengkajian yang mendalam sehingga terjadi beberapa kali revisi dan perbaikan yang dilakukan oleh Pemerintah Provinsi Sulawesi Tenggara dan Direktorat Jenderal Otonomi Daerah, Kementerian Dalam Negeri Republik Indonesia.

Selain itu, proses restrukturisasi dan penataan kelembagaan organisasi 
Kecamatan Tiwu dan Kecamatan Lasusua tidak melibatkan aparatur sipil negara lingkup Kecamatan Tiwu dan Kecamatan Lasusua, sehingga aparatur yang bekerja di instansi tersebut tidak mengetahui adanya penataan kelembagaan atau restrukturisasi organisasi Kecamatan. Hal tersebut berimplikasi pada ketidaktahuan aparatur pemerintah tentang struktur organisasi, tata kerja dan tugas pokok dan fungsi Kecamatan. Tidak adanya sosialisasi peraturan daerah yang dilakukan oleh Pemerintah Daerah mengakibatkan lambatnya proses penyesuaian organisasi perangkat daerah khususnya Kecamatan Tiwu dan Kecamatan Lasusua dengan struktur organisasi, tata kerja dan tugas pokok dan fungsi dengan kelembagaan yang baru.

Selain hal tersebut di atas, ada beberapa permasalahan dalam restrukturisasi organisasi perangkat daerah khususnya Kecamatan Tiwu dan Kecamatan Lasusua. Ada beberapa urusan pemerintahan yang tidak diakomodasi dalam struktur organisasi, tata kerja dan tugas pokok dan fungsi Kecamatan. Permasalahan pertama dapat diamati pada struktur organisasi dan tata kerja Kecamatan Tiwu tidak adanya Seksi Ketentraman dan Ketertiban Umum dan Seksi Pelayanan Sosial, dan urusan tersebut juga tidak diakomodasi oleh Seksi yang lain. Permasalahan kedua adalah terjadinya tumpang tindih (overlapping) dalam urusan pemerintahan di tingkat Kecamatan, yaitu urusan keagrariaan diurus oleh 2 (dua) seksi yaitu Seksi Pemerintahan dan Seksi Pembangunan dan Pemberdayaan Masyarakat Desa, Kemudian urusan penyelenggaraan pembinaan pemerintah Desa/Kelurahan diurus oleh 2 (dua) seksi yaitu Seksi Pemerintahan dan Seksi Pembangunan dan Pemberdayaan masyarakat Desa, hal tersebut dapat mengakibatkan konflik Copyright @ 2018, Publik : (Jurnal Ilmu Administrasi), ISSN: 2301-573X (Print), ISSN: 2581-2084 (Online) kepentingan (conflict of interest) dalam organisasi yang akan menghambat proses pelayanan publik yang prima. Permasalahan yang ketiga adalah ketidakjelasan tugas pokok dan fungsi Seksi Pelayanan Administrasi Terpadu seperti jenis-jenis administrasi dan perizinan yang bisa dilakukan oleh Kecamatan, sehingga bisa melahirkan multi tafsir dalam penyelenggaraan pelayanan administrasi terpadu di Kecamatan, dan harus pula melakukan koordinasi ke instansi / organisasi perangkat daerah terkait pelayanan administrasi terpadu di tingkat Kabupaten, sehingga akan berdampak pada lambatnya proses pelayanan publik di bidang perizinan. Permasalahan keempat adalah kebijakan yang baru tidak memperlihatkan secara jelas dalam pelayanan publik.

Struktur organisasi Kecamatan Tiwu sebelum dan sesudah dilakukannya restrukturisasi organisasi justru memberikan dampak buruk terhadap pelayanan publik karena ada urusan pemerintahan yang tumpang tindih (overlapping) yaitu Seksi Pemerintahan dan Seksi Pembangunan dan Pemberdayaan Masyarakat Desa yang mempunyai 2 (dua) fungsi yang sama sehingga akan berdampak pada ketidakjelasan bagan alir dalam pelayanan publik di Kecamatan.

Selain itu, tidak jelasnya bagan struktur organisasi terkait dengan garisgaris perintah, komando dan.atau instruksi serta garis-garis yang bersifat koordinasi dan/atau konsultasi antara satu pembidangan dengan yang lainnya. Sehingga, dalam menerjemahkan struktur organisasi terjadi multi tafsir dalam pelaksanaan tugas dan fungsinya dalam pelayanan publik. Selain itu, pada kelompok jabatan fungsional belum terlihat secara rinci uraian fungsi-fungsi 
yang dimaksud dalam struktur organisasi Kecamatan.

Tipelogi Perangkat Daerah Kecamatan di Kabupaten Kolaka Utara (Studi Kasus Kecamatan Tiwu dan Kecamatan Lasusua)

1. Kecamatan Tiwu

Variabel Umum pengukuran intensitas urusan pemerintahan dan beban kerja perangkat daerah $(20 \%)$

Tabel 2 Variabel Umum

\begin{tabular}{cccc}
\hline Indikator dan Kelas & Skal & Bobo & Sko \\
Interval & $\mathrm{a}$ & $\mathrm{t}(\%)$ & $\mathrm{r}$ \\
& Nilai & & \\
\hline
\end{tabular}

Jumlah penduduk

(Jiwa)
a. $\leq 100.000$
200
b. 100.001-200.000
400
20
c. 200.001-500.000
600
40
d. 500.001-
800
10
60
1.000 .000
1000
80
100
e. $>1.000 .000$
Luas wilayah $\left(\mathrm{Km}^{2}\right)$
a. $\leq 150$
b. $151-300$
200
400
600
800
1000
d. 451-600
e. $>600$
200
Jumlah APBD (Rp)
a. $\leq$ 250.000.000.000
b. $250.000 .000 .001-$ 500.000 .000 .000

$\begin{array}{ll}400 & 20 \\ 600 & 5\end{array}$
c. 500.000.000.001- 750.000 .000 .000

$\begin{array}{lll}600 \quad 5 & 30\end{array}$
d. 750.000.000.001- 1.000.000.000.00 1000

$800 \quad 40$ 0

e. $>1.000 .000 .000 .0$ 01

Sumber : PP 18 Tahun 2016

Langkah-langkah :

$>$ Indikator \& Kelas Interval = Skala Nilai $\mathrm{x}$ bobot $(\%)=$ Skor

1. Variabel Umum Kabupaten Kolaka Utara (20\%)

- Jumlah penduduk (Jiwa) = $142.614(400 \times 10 \%=40)$
- Luas wilayah $\left(\mathrm{Km}^{2}\right)=3 \quad 391.62$ $(1000 \times 5 \%=50)$

- Jumlah APBD (Rp) = $817.539 .815 .860(800 \times 5 \%=40)$ Jumlah skor variabel umum $=130$

Variabel Teknis pengukuran intensitas urusan pemerintahan dan beban kerja perangkat daerah $(80 \%)$

Tabel 3 Variabel Teknis

\begin{tabular}{cccc}
\hline $\begin{array}{c}\text { Indikator dan } \\
\text { Kelas Interval }\end{array}$ & $\begin{array}{c}\text { Skala } \\
\text { Nilai }\end{array}$ & $\begin{array}{c}\text { Bobot } \\
(\%)\end{array}$ & $\begin{array}{c}\text { Skor } \\
\text { wilayah }\end{array}$ \\
Luas & & \\
kecamatan $\left(\mathrm{Km}^{2}\right)$ & & & \\
a. $\leq 5$ & 200 & & 40 \\
b. $6-10$ & 400 & & 80 \\
c. $11-50$ & 600 & 20 & 120 \\
d. $\mathbf{5 1 - 1 0 0}$ & $\mathbf{8 0 0}$ & & $\mathbf{1 6 0}$ \\
e. $>100$ & 1000 & & 200
\end{tabular}

Jumlah

kelurahan/desa atau nama lain

$\begin{array}{lccc}\text { a. } \leq 5 & 200 & & 70 \\ \text { b. } 6-10 & \mathbf{4 0 0} & & \mathbf{1 4 0} \\ \text { c. } 11-15 & 600 & 35 & 210 \\ \text { d. } 16-20 & 800 & & 280 \\ \text { e. }>20 & 1000 & & 350\end{array}$

Jumlah penduduk

kecamatan

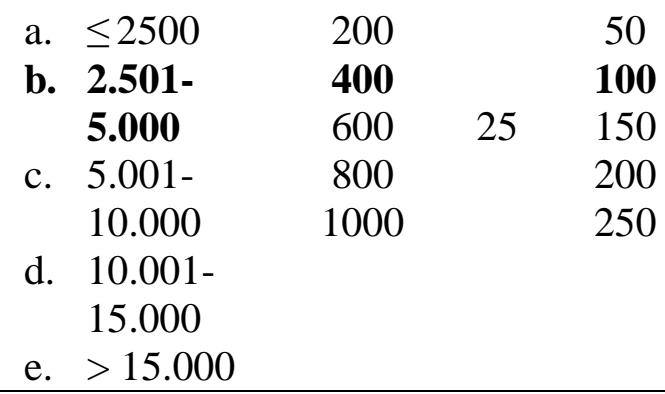

Sumber : PP 18 Tahun 2016

2. Variabel Teknis Kecamatan Tiwu $(80 \%)$

- Luas wilayah kecamatan $\left(\mathrm{Km}^{2}\right)=$ $81,92(800 \times 20 \%=160)$

- Jumlah Desa/Kelurahan = $7(400 \times 35 \%=140)$

- Jumlah penduduk (jiwa) $=4.300(400 \times 25 \%=100)$ Jumlah skor variabel teknis $\quad=400$ 
Publik : (Jurnal Ilmu Administrasi) Vol 7 (1), Juni 2018

Skor Akhir $=$ skor variabel umum + skor variabel teknis $=$ Total Skor

Skor Akhir $=130+400=530$

$>$ Melakukan perkalian jumlah nilai dari seluruh indikator dari variabel umum dan variabel teknis dengan faktor kesulitan geografis (Sulawesi $=1,1$ ) $530 \times 1.1=583$

$>$ Penetapan intensitas urusan pemerintahan dan beban kerja perangkat daerah berdasarkan hasil perhitungan tersebut dengan kriteria sebagai berikut:

- Kecamatan Tiwu Tipe B = Skor 583

2. Kecamatan Lasusua

Variabel Umum pengukuran intensitas urusan pemerintahan dan beban kerja perangkat daerah $(20 \%)$

Tabel 4 Variabel Umum

\begin{tabular}{|c|c|c|c|}
\hline $\begin{array}{l}\text { Indikator dan Kelas } \\
\text { Interval }\end{array}$ & $\begin{array}{l}\text { Skal } \\
\text { a } \\
\text { Nilai }\end{array}$ & $\begin{array}{l}\text { Bobo } \\
\mathrm{t}(\%)\end{array}$ & $\begin{array}{c}\text { Sko } \\
\text { r }\end{array}$ \\
\hline $\begin{array}{l}\text { Jumlah penduduk } \\
\text { (Jiwa) }\end{array}$ & & & \\
\hline a. $\leq 100.000$ & 200 & & 20 \\
\hline b. $100.001-200.000$ & 400 & & 40 \\
\hline c. $200.001-500.000$ & 600 & 10 & 60 \\
\hline d. 500.001- & 800 & & 80 \\
\hline 1.000 .000 & 1000 & & 100 \\
\hline $\begin{array}{l}\text { e. }>1.000 .000 \\
\text { Luas wilayah }\left(\mathrm{Km}^{2}\right)\end{array}$ & & & \\
\hline a. $\leq 150$ & 200 & & 10 \\
\hline b. $151-300$ & 400 & & 20 \\
\hline c. $301-450$ & 600 & 5 & 30 \\
\hline d. 451-600 & 800 & & 40 \\
\hline $\begin{array}{l}\text { e. }>\mathbf{6 0 0} \\
\text { Jumlah APBD (Rp) }\end{array}$ & 1000 & & 50 \\
\hline a. $\leq$ & 200 & & 10 \\
\hline b. $\begin{array}{l}250.000 .000 .001- \\
500.000 .000 .000\end{array}$ & 400 & & 20 \\
\hline $\begin{array}{ll}\text { c. } 500.000 .000 .001- \\
\text { d. } 750.000 .000 .000\end{array}$ & 600 & 5 & 30 \\
\hline $\begin{array}{ll}\text { e. } & 750.000 .000 .001- \\
1.000 .000 .000 .00 \\
0\end{array}$ & 800 & & 40 \\
\hline f. $\begin{array}{l}>1.000 .000 .000 .0 \\
01\end{array}$ & 1000 & & 50 \\
\hline
\end{tabular}

Sumber : PP 18 Tahun 2016
Langkah-langkah :

Indikator \& Kelas Interval = Skala Nilai $\mathrm{x}$ bobot $(\%)=$ Skor

1. Variabel Umum Kabupaten Kolaka Utara (20\%)

- Jumlah penduduk (Jiwa) = $142.614(400 \times 10 \%=40)$

- Luas wilayah $\left(\mathrm{Km}^{2}\right)=$ $3391.62(1000 \times 5 \%=50)$

- Jumlah APBD $(\mathrm{Rp})=$ $817.539 .815 .860(800 \times 5 \%=40)$ Jumlah skor variabel umum $\quad=130$ Variabel Teknis pengukuran intensitas urusan pemerintahan dan beban kerja perangkat daerah $(80 \%)$

Tabel 4.7. Variabel Teknis

\begin{tabular}{|c|c|c|c|}
\hline $\begin{array}{l}\text { Indikator dan } \\
\text { Kelas Interval }\end{array}$ & $\begin{array}{l}\text { Skala } \\
\text { Nilai }\end{array}$ & $\begin{array}{c}\text { Bobot } \\
(\%)\end{array}$ & Skor \\
\hline $\begin{array}{l}\text { Luas wilayah } \\
\text { kecamatan }\left(\mathrm{Km}^{2}\right)\end{array}$ & & & \\
\hline a. $\leq 5$ & 200 & & 40 \\
\hline b. $6-10$ & 400 & & 80 \\
\hline c. $11-50$ & 600 & 20 & 120 \\
\hline d. 51-100 & 800 & & 160 \\
\hline e. $>100$ & 1000 & & 200 \\
\hline Jumlah & & & \\
\hline kelurahan/desa & 200 & & 70 \\
\hline a. $\leq 5$ & 400 & & 140 \\
\hline b. $\overline{6}-10$ & 600 & 35 & 210 \\
\hline c. $11-15$ & 800 & & 280 \\
\hline d. $16-20$ & 1000 & & 350 \\
\hline e. $>20$ & & & \\
\hline $\begin{array}{l}\text { Jumlah penduduk } \\
\text { kecamatan }\end{array}$ & & & \\
\hline a. $\leq 2500$ & 200 & & 50 \\
\hline b. $2.501-5.000$ & 400 & & 100 \\
\hline c. 5.001-10.000 & 600 & 25 & 150 \\
\hline d. 10.001-15.000 & 800 & & 200 \\
\hline e. $>15.000$ & 1000 & & 250 \\
\hline
\end{tabular}

Sumber : PP 18 Tahun 2016

2. Variabel Teknis Kecamatan Lasusua $(80 \%)$

- Luas wilayah kecamatan $\left(\mathrm{Km}^{2}\right)$ $=287,67(1000 \times 20 \%=200)$

- Jumlah Desa/Kelurahan

$$
=12(600 \times 35 \%=210)
$$


- Jumlah penduduk (jiwa)

$$
=28.968(1000 \times 25 \%=250)
$$

Jumlah skor variabel teknis $\quad=660$

$>$ Skor Akhir $=$ skor variabel umum + skor variabel teknis $=$ Total Skor

Skor Akhir $=130+660=790$

$>$ Melakukan perkalian jumlah nilai dari seluruh indikator dari variabel umum dan variabel teknis dengan faktor kesulitan geografis (Sulawesi $=1,1$ ) $790 \times 1.1=869$

$>$ Penetapan intensitas urusan pemerintahan dan beban kerja perangkat daerah berdasarkan hasil perhitungan tersebut dengan kriteria sebagai berikut:

- Kecamatan Lasusua Tipe A = Skor 869

Berdasarkan hasil analisis deskriptif kuantitatif terhadap penentuan tipelogi Kecamatan Tiwu dan Kecamatan Lasusua, maka terdapat perbedaan hasil analisis yang dilakukan oleh pemerintah daerah dan penulis dalam penentuan tipelogi. Tipelogi Kecamatan Tiwu berdasarkan hasil analisis penulis berada pada klasifikasi tipe $\mathrm{B}$, dalam arti kecamatan Tiwu mempunyai beban kerja yang kecil.

Berdasarkan tipelogi organisasi perangkat daerah Kabupaten Kolaka Utara, hasil analisis penulis menunjukkan hasil yang berbeda dengan analisis yang dilakukan oleh Pemerintah Daerah. Hasil analisis beban kerja utama urusan pemerintahan berdasarkan indikator variabel umum dan indikator variabel teknis menunjukkan bahwa Kecamatan Tiwu memperoleh skor 583 hal tersebut berarti Kecamatan tersebut masuk ke dalam tipe B, dalam arti bahwa Kecamatan Tiwu dibentuk dengan beban kerja yang kecil.

Berdasarkan hasil analisis tersebut, pemerintah daerah tidak melakukan analisis dan kajian yang mendalam tentang pembentukan organisasi perangkat daerah khususnya Kecamatan Tiwu. Pemerintah daerah harus melakukan revisi dan perbaikan terhadap analisis beban kerja utama urusan pemerintahan dalam variabel umum dan variabel teknis dalam penentuan tipelogi dan besaran organisasi khususnya Kecamatan Tiwu yang tidak rasional serta belum efektif dan efisien.

Pembentukan Kecamatan Tiwu sebagai organisasi dengan beban kerja yang besar berimplikasi pada alokasi anggaran operasional Kecamatan, struktur organisasi dan tata kerja Kecamatan, tugas pokok dan fungsi Kecamatan. Padahal, setelah penulis melakukan analisis dalam penentuan tipelogi dan besaran organisasi, Kecamatan Tiwu berada dalam tipe Kecamatan B, dalam arti bahwa organisasi kecamatan dengan beban kerja yang kecil dengan 1 Sekretariat, 2 Sub bagian, dan 4 Seksi. Oleh karena itu, pemerintah daerah harus melakukan revisi dan perbaikan terhadap kebijakan yang telah dikeluarkan tersebut.

Berdasarkan tipelogi organisasi perangkat daerah Kabupaten Kolaka Utara, hasil analisis penulis menunjukkan hasil yang sesuai dengan analisis yang dilakukan oleh Pemerintah Daerah. Hasil analisis beban kerja utama urusan pemerintahan berdasarkan indikator variabel umum dan indikator variabel teknis menunjukkan bahwa Kecamatan Lasusua memperoleh skor 869 hal tersebut berarti Kecamatan tersebut masuk ke dalam tipe A, dalam arti bahwa Kecamatan Lasusua dibentuk dengan beban kerja yang besar.

Berdasarkan hasil analisis tersebut, pemerintah daerah telah melakukan analisis dan kajian yang mendalam tentang pembentukan organisasi perangkat daerah khususnya Kecamatan Lasusua. Pembentukan Kecamatan Lasusua sebagai organisasi dengan beban kerja yang besar 
berimplikasi pada alokasi anggaran operasional Kecamatan, struktur organisasi dan tata kerja Kecamatan, tugas pokok dan fungsi Kecamatan. Setelah penulis melakukan analisis dalam penentuan tipelogi dan besaran organisasi, Kecamatan Lasusua sudah berada dalam tipe Kecamatan A, dalam arti bahwa organisasi kecamatan dengan beban kerja yang besar dengan 1 Sekretariat, 2 Sub bagian, dan 5 Seksi. Oleh karena itu, pemerintah daerah harus dapat memberikan dukungan kebijakan khususnya terkait dengan alokasi anggaran dalam rangka operasionalisasi program kerja dan kegiatan-kegiatan di Kecamatan Lasusua, serta dukungan sumber daya manusia melalui Aparatur Sipil Negara yang berkualitas dalam rangka penyelenggaraan pemerintahan khususnya dalam pelayanan publik. Berdasarkan pembahasan sebagaimana dijelaskan di atas, maka penentuan tipelogi Kecamatan Tiwu dan Kecamatan Lasusua belum berdasarkan analisis beban kerja utama urusan pemerintahan dalam variabel umum dan variabel teknis secara rasional, efektif dan efisien.

Secara umum, proses restrukturisasi organisasi perangkat daerah kecamatan di Kabupaten Kolaka Utara khususnya Kecamatan Tiwu dan Kecamatan Lasusua belum melalui proses restrukturisasi organisasi dan analisis terhadap variabel umum dan variabel teknis sebagaimana dijelaskan dalam Peraturan Pemerintah Nomor 18 Tahun 2016, Proses restrukturisasi tidak berjalan dengan baik disebabkan oleh beberapa faktor seperti kepanitiaan, tim perumus dan analisis terhadap organisasi perangkat daerah kecamatan, sehingga berdampak terhadap hasil analisis dan diagnosa organisasi yang dihasilkan dalam Peraturan Daerah dan Peraturan Bupati. Selain itu, penjabaran tugas pokok dan fungsi, struktur organisasi dan tata kerja organisasi Kecamatan yang Copyright O 2018, Publik : (Jurnal Ilmu Administasi), ISSN :2301-573X (Print), ISSN : 2581-2084 (Online) tumpang tindih (overlapping) dan tidak jelasnya bagan alir dalam struktur organisasi.

\section{Besaran Organisasi Perangkat Daerah (Studi Kasus: Kecamatan Tiwu dan Kecamatan Lasusua)}

Penentuan tipe organisasi Kecamatan Tiwu dan Kecamatan Lasusua dianalisis oleh pemerintah daerah (tim perumus) melalui Bagian Organisasi dan Tata Laksana Sekretariat Daerah Kabupaten Kolaka Utara, kemudian disahkan menjadi Peraturan Daerah di DPRD Kabupaten Kolaka Utara. Sebagaimana hasil wawancara penulis dengan informan sebagai berikut :

"tipe organisasi Kecamatan Tiwu

dan Kecamatan Lasusua di

Kabupaten Kolaka Utara tersebut diukur dengan melihat hasil klasifikasi tipe kecamatan, dengan menggunakan variabel umum dan variabel teknis" (wawancara, " $R$ ", Kasubag Kelembagaan, Bagian Ortala Setda, 30 Oktober 2017)

Hasil wawancara tersebut sejalan dengan penjelasan yang diberikan oleh Kepala Bagian Organisasi dan Tata Laksana Sekretariat Daerah Kabupaten Kolaka Utara, sebagaimana hasil wawancara penulis dengan informan sebagai berikut :

"hasil analisis pemerintah daerah yang kemudian ditetapkan dalam peraturan daerah bahwa Kecamatan Tiwu dan Kecamatan Lasusua bertipe A begitupula dengan seluruh kecamatan yang ada " (wawancara, "I", Kepala Bagian Ortala Setda, 5 November 2017)

Berdasarkan hasil wawancara sebagaimana dijelaskan di atas, pada dasarnya Kecamatan Tiwu dan Kecamatan Lasusua berdasarkan hasil kategorisasi tipe klasifikasi kecamatan, kedua Kecamatan tersebut bertipe A dalam hal ini berada ), ISSN: 2301-573X (Print), ISSN: 2581-2084 
pada kategori beban kerja yang besar. Oleh karena itu, konsekuensi Kecamatan yang bertipe A akan berdampak pada besaran organisasinya seperti struktur organisasi, penjabaran tugas dan fungsi, dan tata kerja baik tata kerja yang bersifat vertikal maupun horizontal. Begitu pula dari aspek pendanaan rutin operasional di setiap Kecamatan semestinya mempunyai besaran alokasi anggaran yang berbedabeda pula.

Akan tetapi, besaran organisasi Kecamatan Tiwu dan Kecamatan Lasusua tersebut tidak sejalan dengan lahirnya Peraturan Bupati Kolaka Utara Nomor 58 Tahun 2016 yang terlihat jelas dalam bagan struktur organisasi yang berbeda, penjabaran tugas pokok dan fungsi di setiap lini organisasi yang berbeda.

Berdasarkan besaran organisasi perangkat daerah Kecamatan Tiwu sebagaimana dijelaskan pada bagian hasil penelitian, maka penentuan besaran organisasi Kecamatan Tiwu dan Kecamatan Lasusua dilakukan melalui perhitungan keberadaan Kecamatan Tiwu dan Kecamatan Lasusua berada dalam kategori dan klasifikasi indikator jumlah penduduk Kabupaten Kolaka Utara, luas wilayah Kabupaten Kolaka Utara dan jumlah Anggaran Pendapatan dan Belanja Daerah (APBD) Kabupaten Kolaka Utara. Selain itu, besaran organisasi mempertimbangkan indikator teknis yaitu jumlah penduduk masing-masing Kecamatan, Jumlah Desa/Kelurahan masing-masing Kecamatan dan luas wilayah masing-masing Kecamatan.

Pada dasarnya Kecamatan Tiwu dan Kecamatan Lasusua berdasarkan hasil kategorisasi tipe klasifikasi kecamatan, kedua Kecamatan tersebut bertipe A dalam hal ini berada pada kategori beban kerja yang besar. Oleh karena itu, konsekuensi Kecamatan yang bertipe A akan berdampak pada besaran organisasinya seperti struktur organisasi, penjabaran tugas dan fungsi, dan tata kerja baik tata kerja yang bersifat vertikal maupun horizontal. Begitu pula dari aspek pendanaan rutin operasional di setiap Kecamatan semestinya mempunyai besaran alokasi anggaran yang berbedabeda pula.

Akan tetapi, besaran organisasi Kecamatan Tiwu dan Kecamatan Lasusua tersebut tidak sejalan dengan lahirnya Peraturan Bupati Kolaka Utara Nomor 58 Tahun 2016 yang terlihat jelas dalam bagan struktur organisasi yang berbeda, penjabaran tugas pokok dan fungsi di setiap lini organisasi yang berbeda. Hal tersebut terjadi perbedaan karena dalam penyusunan bagan struktur organisasi Tim Perumus dalam hal ini Bagian Organisasi dan Tatalaksana Sekretariat Daerah melakukan pengklasifikasian terhadap seluruh kecamatan dengan mempertimbangkan jumlah penduduk dan jumlah Desa/Kelurahan.

Pada dasarnya Kecamatan Tiwu dan Kecamatan Lasusua bertipe A. Akan tetapi, tipelogi Kecamatan Tiwu dan Kecamatan Lasusua tidak berbanding lurus dengan peraturan teknis operasional sebagaimana dijelaskan dalam Peraturan Bupati. Oleh karena itu, besaran organisasi Kecamatan Tiwu dan Kecamatan Lasusua belum efektif, efisien dan rasional karena keluar dari Peraturan Pemerintah Nomor 18 Tahun 2016 tentang Perangkat Daerah.

Besaran organisasi Kecamatan Tiwu dan Kecamatan Lasusua tersebut perlu diperbaiki dalam penyusunan Struktur Organisasi dan Tata Kerja (SOTK), penjabaran tugas pokok dan fungsi disetiap lini / seksi yang ada di Kecamatan. Oleh karena itu, landasan hukum dan kebijakan daerah dalam penyusunan besaran organisasi Kecamatan tersebut masih 
terdapat kelemahan yang harusdi perbaiki. Selain itu, Kecamatan Tiwu dan Kecamatan Lasusua hasil restrukturisasi organisasi diisi oleh pimpinan yang mempunyai latar belakang non pemerintahan, Camat Tiwu berkualifikasi Sarjana Pendidikan, sedangkan Camat Lasusua berkualifikasi Sarjana Pertanian. Hal tersebut tidak sejalan dalam pengelolaan organisasi yang efektif yaitu the right man on the right place dalam manajemen sumber daya manusia aparatur.

$$
\text { Menurut Rivai (2003) dalam }
$$

(Subekhi dan Jauhar, 2012), bahwa penataan sumber daya manusia dalam proses reformasi birokrasi dapat diartikan sebagai suatu bentuk pendekatan manajemen sumber daya manusia. Dalam Perspektif reformasi birokrasi, pendekatan ini dilakukan dalam rangka menyikapi, mengatasi, dan sekaligus mengantisipasi permasalahan sumber daya manusia dalam birokrasi. Selain itu, Menurut Sedarmayanti (2009:94) pengukuran mengenai penataan sumber daya manusia aparatur dilaksanakan dengan memperhatikan: (1) penerapan sistem merit dalam manajemen kepegawaian, (2) sistem diklat yang efektif, (3) standar dan peningkatan kinerja; (4) Pola karier yang jelas dan terencana, (5) standar kompetensi jabatan, (6) kualifikasi jabatan, (7) tugas, fungsi dan beban tugas proporsional, (8) rekrutmen sesuai prosedur, (9) penempatan pegawai sesuai keahlian, (10) renumerasi memadai, (11) perbaikan sistem manajemen kepegawaian Oleh karena itu, berdasarkan proses restrukturisasi organisasi perangkat daerah kecamatan, proses penentuan tipelogi dan besaran Kecamatan Tiwu dan Kecamatan Lasusua tersebut maka perlu melakukan reformasi di sektor birokrasi khususnya terkait dengan manajemen sumber daya manusia aparatur, belum berdasarkan indikatorindikator teoretis yang rasional, disebabkan Copyright @ 2018, Publik : (Jurnal Ilmu Administrasi), ISSN: 2301-573X (Print), ISSN: 2581-2084 (Online) oleh penempatan pegawai tidak sesuai dengan bidang keahlian karena Kecamatan Tiwu dan Kecamatan Lasusua tersebut diisi oleh aparatur yang berkualifikasi pendidikan non pemerintahan dan administrasi publik. Sehingga akan berdampak pada penyelenggaraan tugas dan fungsi administrasi dan pemerintahan sehingga akan memberikan dampak secara luas dalam pelayanan publik.

Selain itu, proses restrukturisasi organisasi perangkat daerah Kecamatan Tiwu dan Kecamatan Lasusua belum berhasil mencapai tujuan restrukturisasi orgaisasi Restrukturisasi tidak bisa dilihat hanya dari perampingan organisasi, sumber daya manusia, atau kinerjanya saja akan tetapi juga harus diperhatikan bahwa restrukturisasi adalah sebuah sistem yang saling mempengaruhi satu sama lainnya dalam pencapaian tujuan organisasi. Proses restrukturisasi organisasi, penentuan tipelogi dan besaran organisasi perangkat daerah kecamatan masih terdapat beberapa kelemahan dalam desain organisasi sebagaimana yang dikemukakan oleh Don Helriegel (2001) bahwa secara prinsip, desain organisasi harus mampu : (a) menyalurkan informasi dan pembuatan keputusan berdasarkan kepentingan stakeholders, (b) menentukan kewenangan dan tanggung jawab dalam tugas, bagian dan departemen, (c) menyeimbangkan integrasi antara pekerjaan, tim, departemen dan bagian, dengan kemampuan adaptasi terhadap perubahan lingkungan. Oleh karena itu, perlu melakukan revisi terhadap desain kelembagaan Kecamatan Tiwu dan Kecamatan Lasusua berdasarkan prinsipprinsip desain organisasi sebagaimana yang dijelaskan di atas, sehingga proses restrukturisasi organisasi, penentuan tipelogi dan besaran organisasi tersebut dilaksanakan secara efektif, efisien dan rasional. 


\section{PENUTUP}

\section{Kesimpulan}

1. Proses restrukturisasi organisasi perangkat daerah di Kabupaten Kolaka Utara khususnya dalam redesain kelembagaan Kecamatan Tiwu dan Kecamatan Lasusua, belum melalui tahapan-tahapan dan proses penataan kelembagaan yang efektif dan efisien, proses pembentukan tim perumus (kepanitiaan), proses politik penetapan kebijakan, proses penentuan tipe dan besaran organisasi Kecamatan, Struktur Organisasi dan Tata Kerja, Tugas Pokok dan Fungsi Kecamatan yang masih tumpang tindih (overlapping) antara satu urusan dengan urusan yang lain, serta kurangnya sosialisasi kebijakan penataan kelembagaan sehingga belum terwujudnya proses restrukturisasi organisasi Kecamatan yang rasional, efektif dan efisien.

2. Penentuan tipelogi organisasi Kecamatan Tiwu dan Kecamatan Lasusua belum berdasarkan analisis urusan pemerintahan dalam variabel umum dan variabel teknis secara rasional, efektif dan efisien.

3. Penyusunan besaran desain organisasi Kecamatan Tiwu dan Kecamatan Lasusua belum berdasarkan mempertimbangkan aspek rasionalitas dalam Peraturan Pemerintah Nomor 18 Tahun 2016 serta indikator dalam manajemen sumber daya manusia aparatur dan prinsip desain organisasi yang rasional.

\section{Saran}

Berdasarkan simpulan sebagaimana dijelaskan di atas maka adapun saran penulis adalah sebagai berikut :

1. Pemerintah Kabupaten Kolaka Utara melalui Bagian Ortala Sekretariat Daerah harus melakukan analisis dan kajian mendalam dalam menentukan tipelogi dan besaran organisasi Kecamatan Tiwu dan Kecamatan Lasusua yang berimplikasi pada kedudukan, Struktur Organisasi dan Tata Kerja (SOTK), Tugas Pokok dan Fungsi (TUPOKSI) Kecamatan dalam rangka analisis organisasi publik yang rasional, efektif dan efisien.

2. Perlu melakukan revisi dalam Peraturan Daerah Nomor 3 Tahun 2016 dan Peraturan Bupati Kolaka Utara Nomor 58 Tahun 2016 dalam penjabaran tugas dan fungsi, tata kerja dan struktur organisasi Kecamatan Tiwu dan Kecamatan Lasusua, dengan memperhatikan indikator penting dalam manajemen sumber daya manusia aparatur dan prinsip-prinsip desain organisasi yang rasional.

3. Pemerintah Kabupaten Kolaka Utara harus memberikan dukungan sumber daya agar kebijakan restrukturisasi organisasi Kecamatan Tiwu dan Kecamatan Lasusua dapat terimplementasi dengan baik salah satunya adalah sumber daya finansial sebagaimana dijelaskan oleh Edwards III dalam Subarsono (2005) bahwa walaupun isi kebijakan sudah dikomunikasikan secara jelas dan konsisten, tetapi apabila implementor kekurangan sumber daya untuk melaksanakan, implementasi tidak akan berjalan efektif. Sumber daya tersebut dapat berwujud sumber daya manusia, yakni kompetensi implementor dan sumber daya finansial. Sumber daya adalah faktor penting untuk implementasi kebijakan agar efektif. Tanpa sumber daya, kebijakan hanya tinggal di kertas menjadi dokumen saja. 


\section{DAFTAR PUSTAKA}

Abady, A. P. (2013). Perencanaan Partisipatif Dalam Pembangunan Daerah. Otoritas: Jurnal Ilmu Pemerintahan, 3(1).

Badan Pusat Statistik Kab. Kolaka Utara, 2017. Kabupaten Kolaka Utara dalam Angka.

Badan Pusat Statistik Kab. Kolaka Utara, 2017. Kecamatan Lasusua dalam Angka.

Badan Pusat Statistik Kab. Kolaka Utara, 2017. Kecamatan Tiwu dalam Angka.

Gitosudarmo, Indriyo. (2001). Manajemen Strategis. Yogyakarta : BPFE

Handoko, T. Hanny, (2006). Manajemen Personalia dan Sumberdaya Manusia. Yogyakarta : BPFE.

Hatch, M. J., 1997. Organization Theory and Theorizing : Modern, Symbolic-Interpretive and Postmodern Perspective. Oxford : Oxford University Press.

Kusdi, (2011). Teori Organisasi dan Administrasi. Jakarta : Penerbit Salemba Humanika.

Mahsyar, A. (2011). Masalah Pelayanan Publik di Indonesia dalam Perspektif Administrasi Publik. Otoritas: Jurnal Ilmu Pemerintahan, 1(2).

Peraturan Bupati Kolaka Utara Nomor 58 Tahun 2016 tentang Kedudukan, Susunan Organisasi, Tata Kerja Kecamatan dan Kelurahan.

Peraturan Daerah Kabupaten Kolaka Utara Nomor 3 Tahun 2016 tentang Pembentukan dan Susunan Organisasi Perangkat Daerah Kabupaten Kolaka Utara.

Peraturan Pemerintah Republik Indonesia Nomor 18 Tahun 2016 tentang Perangkat Daerah.
Prianto, A. L. (2011). Good Governance dan Formasi Kebijakan Publik Neo-Liberal. Otoritas: Jurnal Ilmu Pemerintahan, 1(1).

Robbins, AG., (2008). Analysis and Approach of Government Science. Manchester : Manchester University Press

Sedarmayanti. (2009). Manajemen Sumber Daya Manusia, Reformasi Birokrasi dan Manajemen Pegawai Negeri Sipil. Bandung: Rafika Aditama

Subarsono, AG. (2005). Analisis Kebijakan Publik. Yogyakarta : Pustaka Pelajar.

Subekhi, Akhmad, Mohammad Jauhar, (2012). Pengantar Manajemen Sumber Daya Manusia. Jakarta : Prestasi Pustaka

Sugiyono, (2017). Metode Penelitian Kuantitatif, Kualitatif dan $R \& D$. Bandung : Alfabeta.

Undang-Undang Nomor 23 Tahun 2014 tentang Pemerintahan Daerah.

Usman, J. (2011). Implementasi Kebijakan Tata Kelola Pemerintahan Daerah Dengan Semangat Euforia Demokrasi Lokal. Otoritas: Jurnal Ilmu Pemerintahan, 1(1).

Usman, J. (2011). Manajemen Birokrasi Profesional dalam Meningkatkan Pelayanan Publik. Otoritas: Jurnal Ilmu Pemerintahan, 1(2).

Wasistiono, Sadu. (2010). Desentralisasi dan revitalisasi lokal (decentralization and local revitalization). Seminar IndonesiaJepang Tanggal 26 dan 27 Oktober 2010. Jatinangor: Kampus IPDN. 